Journal of English Language Teaching

UNNES

\title{
Short-animation video in web meeting classes for secondary school learners' EFL writing achievement
}

\author{
Dwi Nikita Sari ${ }^{1}$, Susilo Susilo ${ }^{\bowtie 2}$, Efendi Limbong ${ }^{3}$
}

${ }^{1,2,3}$ English Department, FKIP, Mulawarman University

\begin{tabular}{l} 
Article Info \\
\hline Article History: \\
Received in 1 Januari \\
2021 \\
Approved in 3 March \\
2021 \\
Published in 26 March \\
2021 \\
\hline Keywords: \\
EFL Writing; Secondary \\
School learners; \\
Short animation video; \\
Web meeting circumstances \\
\hline
\end{tabular}

\begin{abstract}
The study aims at investigating whether there is an effect of short animation video on the EFL narrative writing achievement of the secondary school EFL learners in the circumstance where web meeting was becoming the class. The study was an experimental study using Static Group Comparison Design. Respondents participated in the study were the $8^{\text {th }}$ Graders of Junior High School. There were 32 students in the experimental group and the other 32 students in the control group. The data were collected by conducting writing tests, i.e. post-test for both the experimental and control groups. Independent sample t-test was used to test the significant difference for pre and post-test scores. The results revealed that the students under the experimental group $(\mathrm{M}=83.22, \mathrm{SD}=7.979, \mathrm{~N}=32)$ performed higher in scores on their narrative writing achievement than the students under the control group $(\mathrm{M}=76.00, \mathrm{SD}=9.824, \mathrm{~N}=32), \mathrm{t}(32)=3.227, \mathrm{p}<.002$, two-tailed. It means there is a significant difference between narrative writing achievement of the students under the experimental group and those under the control group. This finding implies there is a significant effect of short animation video on the narrative EFL writing achievement of the secondary school EFL learners.
\end{abstract}

(C) 2021 Universitas Negeri Semarang

${ }^{\square}$ Correspondent Address:

B3 Building FBS Unnes

p-ISSN 2252-6706 | e-ISSN 2721-4532

Sekaran, Gunungpati, Semarang, 50229

E-mail: airafsusiloReno111@yahoo.com 


\section{INTRODUCTION}

To fit for the disruption of the normal function of education since the covid-19 outbreak began to run its course, students, teachers, and leaders of education had put in place various alternative ways to continue all the businesses of education. Due to the restriction of people congregating in public place, all educational institutions had to prefer choosing virtual meeting classes to continue the process of teaching and learning. As a result, to explore various innovations of the online meeting class has been becoming new challenges for all teachers to obtain a bright sustainable future. Such a sustainable future might strongly presumably be related to the interaction with digital resources (Flores, 2020; Napal et al., 2020; Rosa et al., 2016). At the same time, digital resources may bring teachers to shift their roles to be more active, innovative, critical, open-minded, driving them to manage, mentor, and motivate their students in digital learning environment (Amin, 2016). That is why, it is necessary for teachers to have virtual-web meetings with learners in order that they are able to help students navigate complex communication situations in a digital environment (O'Dowd et al., 2019). Apparently, using technology-based media in web meeting circumstance of learning is a panacea.

There are numerous technology-based media used in teaching EFL writing, one of which is a video. As what Richards \& Renandya (2002) elaborated about video, compared to other visual media, video covers more quite heavy sense in terms of an access to learners' experiences which might make the learners easily digest materials given. According to Cakir (2006), media and styles of visual presentation are useful for language learners. In addition, Smaldino et al., (2011) argued that numerous teachers use videos for various ends since short video might give more flexible media in teaching in the classroom. Especially for animation video, it is quite useful to be a means of leading learners in optimal learning. Presumably, teaching EFL writing by using animation video has been evidently claimed effective.

The claim about effectiveness of teaching EFL writing by using a short animation video has been proved by some research findings. Numerous previous studies were conducted to investigate technology-based media in EFL teaching by mentioning various platform of technology, among others are explainer video, short animations with dialogue, short video, short English video, plotagon, tailormade animated cartoons, modalities of videos, short stories through computers, WhatsApp group, and silent short movie as pedagogical terms which were related to video as media in teaching, being claimed to give a significant effect on the students' achievement in EFL narrative writing (see Akib \& Syatriana, 2019; Bakla, 2019; Guzmán Gámez \& Moreno Cuellar, 2019; Marashi \& Adiban, 2017; Haslida, 2019; Irawati, 2016; Masruddin, 2018; Kartika et al., 2017; Umutlu \& Akpinar, 2020; Wahyuni \& Febianti, 2019; Yilmaz, 2015). Most of those previous findings are strengthening the use of video as media in learning. Having a stronger notion on the effectiveness of video usage in EFL teaching since many previous findings have been conducted, animation video functioned as helpful media in teaching EFL writing apparently shows its significance.

In terms of EFL writing, using short video as media in learning has been proved as a panacea of healing some learners' barriers in accomplishing their achievement. For instance, silent movie was proved as effective media in EFL writing achievement of vocational school students (Kartika et al., 2017); short movie was claimed as effective media to teaching speaking senior high school students (Masruddin, 2018); and short video animation was evidently seen as effective media in writing in Tehran language learners (Marashi \& Adiban, 2017). Moreover, Machili et al., (2020) were interested in conducting research on the role of video in the integrated writing and strategy instruction (SI) in English for academic purposes (EAP). The findings suggested positive impact of SI on the integrated writing performance. To mention some, those studies are dealing with video in the form of short movie, accept Marashi \& Adiban's (2017) study, in the Asian context of EFL as prototype of large class learning. However, spesifically researches on the use of animation video for learners of EFL writing in larger classes are still rarely done. It is obvious that investigation on the animation video as media in learning ELF writing class needs more wider practical perspectives. This current study appeared to strengthen the wide prism of technology praxis in EFL teaching, especially in EFL writing for the larger classes in Indonesian secondary schools. Moreover, as one of the most effective media used in the teaching during the pandemic outbreak circumstances, animation video functioned to be a means for transferring messages in the process of teaching in such condition. Especially this study proposed a research question of 'is there any significant effect of short animation video on the EFL narrative writing achievement of the $8^{\text {th }}$ Graders of Junior High School?'. 


\section{Literature Review \\ Writing Process}

The Writing is someone's ability to compose stretches of words into meaningful forms of communicative means in order that he/she shows communicative skills for good way of expressing ideas in an purposive end (Celce-Murcia \& Olshtain, 2000; Harmer, 2007). The process of writing consists of pre writing, drafting, and revising. In addition, there are many ways in the process of organizing paragraphs in writing, in which the writer's purposes can be clearly defined (Smalley et al., 2001). Differently, Langan (2008) divided the writing process into four types, they are:

a) Pre writing

This is a phase where writer starts to think of what to write. At least Langan argued several strategies in having such pre writing, i.e. questioning, making a list, clustering, mapping, or preparing an outline.

b) Writing a first draft

This phase is real writing phase where writer should put ideas on paper, starting to prepare what it will be for initial draft.

c) Revising

Once writer gets his/her ideas put in the paper as drafts, he/she should see again whether the ideas are put a good way. In this case, there is a need for writer to rewrite everything she/he wants to revise.

d) Editing

This is the phase of checking anything related to grammatical mistakes, punctuation, spelling etc.

Furthermore, the purpose of writing is to express ideas, convey messages to the readers; therefore, the ideas should arguably be seen as the most important aspect of the writing. Diction and sentence structures are similarly important in conveying messages. According to (Grenville, 2001) at least there are three purposes of writing:

a) to entertain writing deliberately designed for entertainment usually provides more imaginary or creative writing forms. It means that the writer needs to use his/her creativity to write.

b) to inform writing aimed at informing something is included in this purpose. This kind of writing will lead writers to focus their writing on objects, places, procedures, or events. It can be seen in newspaper and articles, scientific or business reports, instructions or procedures, and essays for school and university.

c) to persuade

The writer tries to convince the reader of something that a point of view is valid by presenting the fact/data so that readers follow writer's opinions and act upon it.

In short, writing aims at not only expressing ideas, feelings or thought in written symbol but entertaining, informing and persuading readers.

In addition to the writing process, something that is important to know is the organization of the paragraphs in writing. There are many ways in the process of organizing paragraphs in writing, in which the writer's purposes can be clearly defined; among others is narrative. In a narrative paragraph, the writer describes a sequence of past events (Smalley et al., 2001). moreover, Knapp \& Watkins, (2005) stated that there are three generic structures in narrative composition, i.e. orientation, complication and resolution. Meanwhile, according to It can be concluded that narrative text is one of the text genres which is constructed by developing three different generic structures, i.e. orientation, complication, and resolution. Orientation deals with the introduction of the character, time, and the place; complication is problems or the conflicts which happen in the story and they have to be solved by the character; while, resolution is the solution of the problems.

\section{Video as Media of Teaching}

Smaldino et al., (2011) traced the term 'media' from the Latin language 'medium which means 'Intermediary'. Therefore, media can be labelled as an intermediary message source to a receiver. By this term means it referred to ways to communicate an information. The format of media is more in 
the terms of form, where a message is incorporated and displayed. According to (Mahajan, 2012), media can be classified into six categories, namely:

a) Graphic media: any kinds of printed media. Things like charts, posters, graphs, photographs, maps books, pictures, or diagrams are incorporated in this medium.

b) Media for display: a tool like a board. The examples are peg boards, bulletin board, chalkboard, or flannel board.

c) Three-dimensional media: a medium that has 3D shape. For example, models, objects, specimens, puppets.

d) Media for projection: a technology device for displaying message like projector. For example, slides, filmstrips, transparencies, films, video tapes, gramophones, records.

e) Audio device: a tool for audio function, such as radio, audio cassettes, gramophones, records.

f) Audio-visual media: a technology device which covers both audio and visual senses, for instance, televisions, computers, videocassettes, or CD.

g) Media for activity: a technology tool that catches motion activities. For example, fieldtrips, dramatization, demonstration, and role-playing.

Referring to such classification, it is apparent that video means a medium that provides audiovisual domain useful for helping the teaching and learning. It can be played back in a slow motion hence human eyes are able to see events occurring too fast in order that the normal vision is registered. In addition, the use of meaningful video in teaching might be the most appropriate for introductory courses, courses of complex topics, lower achieving-students, and visual/spatial learners. Videos can also operate recorded-pictures display on television-type screen (Newby, 2002). Richards \& Renandya (2002), furthermore, elaborated that as audio-visual media, video incorporates more extremely heavy senses in terms of an access to learners' experiences which might make the learners easily digest materials given. It means that video incorporates visual and audio effects. In the context of teaching, Brewster et al., (2002) concludes some benefits of using videos for young learners into four aspects as follows:

a) Teaching and learning can get psychological aspect of watching video in terms of various ways, such the fact that the learners find video fun, stimulating and highly motivating. In addition, the learning experience successful in class, the positive attitudes appeared in class, and feeling confident are things that video can contribute to the classroom.

b) All factors of communication, such as language forms, nonverbal codes, meaning negotiation, and interaction are the linguistic aspect of video that can be presented to represent new words, phrases, and expressions of messages. It is all showed by the video consequently learning can be more accessible and memorable.

c) The increase of learners' curiosity and up-to-date information can be provided in the cognitive aspect of video. It enables learners to maximize their abilities to infer form context. In addition, learners' motoric abilities, research knowledge and experiences, abilities to communicate, autonomous learning can be developed through video.

d) In terms of cultural aspect, video enables learners to see the world beyond the classroom and improves their cultural awareness.

However, despite the strength of video as media in learning, Riddel, (2003) stated some disadvantages of using video as media. The weakness is regarded with lack of naturalness in learning when using video. It is not rare that learners feel frustrated with the 'stop-start' nature of lesson; in addition, with a very big class, not everyone may be able to see the screen. In a nutshell, using video as media of learning might either provide advantages and disadvantages depending on how we as teachers develop media in the circumstances in such as a way that students are able to feel secure and fun in learning. Indeed, media should be helpful in the classroom.

\section{Teaching EFL Writing and Short Animation Video}

Various research findings proved the claim about effectiveness of teaching EFL writing by using short animation video. Such findings showed investigation of video as media in EFL teaching by mentioning various models of short video; namely, explainer video, short animations with dialogue, short video, short English video, plotagon, tailor-made animated cartoons, modalities of videos, short stories through computers, WhatsApp group, and silent short movie as pedagogical terms which were 
related to video as media in teaching, being claimed to give a significant effect on the students' achievement in EFL narrative writing (see Kartika et al., 2017; Akib \& Syatriana, 2019; Bakla, 2019; Guzmán Gámez \& Moreno Cuellar, 2019; Marashi \& Adiban, 2017; Haslida, 2019; Irawati, 2016; Masruddin, 2018;; Umutlu \& Akpinar, 2020; Wahyuni \& Febianti, 2019; Yilmaz, 2015).

Furthermore, of the mentioned previous findings, some were conducted in Asian contexts in which learners were engaged in large classes. For instance, Kartika et al., (2017) involved participants of 61 Indonesian vocational high school students. This study intended to investigate the effect of silent movie on their EFL writing achievement. The findings showed that students who were taught by silent short movie got significantly different achievement in EFL writing than did the students who were not taught by silent short. In addition, Masruddin (2018) studying the effectiveness of short movie in teaching speaking skills of the 25 eleventh grade students of SMAN 4 Luwu in Luwu Regency, South Sulawesi Province, Indonesia. It was proven by the data that there was a significant difference between the students' mean score of pretest and posttest. Moreover, Masruddin (2018), using 60 preintermediate EFL learners from a language school in Tehran as participants of experimental and control group. In both groups, the participants were asked to write five writings regarding the subjects of the animations during the term and each of the writings should have contained a minimum of 90 and maximum of 140 words. The results revealed that the experimental group outperformed the control group.

\section{METHODS}

\section{Research Design}

The study was an experimental study using Static Group Comparison Design. There were two nonrandomized groups, i.e. experimental and control group as it is shown in table 1. Teaching narrative text by using short animation video was the independent variable and students' EFL narrative writing achievement was the dependent variable in the study.

Table 1. Static Group Comparison Design

\begin{tabular}{ccc}
\hline Group & Independent Variable & Post-Test \\
\hline Experimental Group & $\mathrm{X}$ & $\mathrm{O}_{2}$ \\
\hline Control Group & - & $\mathrm{O}_{2}$ \\
\hline
\end{tabular}

\section{Research subjects}

Respondents participated in the study were the $8^{\text {th }}$ grade students of Junior High School. There were two classes used as samples in the study. They were the VIII B class, as the experimental group, consisting of 32 students and the VIII D class, as the control group, containing 32 students. Those samples were taken from the population by using cluster random sampling technique. Those sample classes were taken from the 160 students who were gathered in 5 parallel classes as the population of the study.

\section{Research procedure}

The data were collected by conducting writing post-tests, i.e. for experimental group and control group. The writing tests were conducted by giving the students writing prompts to write narrative texts after the treatments were done to both groups. The treatment was conducted virtually using online platform, i.e. google classroom (the treatment activities was wrapped up in table 2.) and so was the administration of the pretest and posttest. The treatment activities were done for 45 minutes in every meeting (i.e. one meeting was named as one treatment and there were four meetings in a whole), therefore totally the time that the researchers needed to conduct the experiment was 180 minutes.

Writing prompts were given to the respondents to write narrative texts after the treatments were done to both groups. The treatment was done virtually using online platform, i.e. google classroom.

In regard with data analysis, researchers used independent sample t-test. Firstly, the descriptive analysis was used to elaborate the mean and the standard deviation of the scores. Then, after the percentage scores for pre and post-test were collected from different groups of students, the independent sample t-test was used to test the significant difference for pre and post-test scores. The independent sample t-test was conducted to test the hypothesis of the study, as follows: 
H0: Teaching narrative text by using animation video do not give statistically significant difference on students' narrative writing achievement before and after the treatment.

H1: Teaching narrative text by using animation video gives statistically significant difference on students' narrative writing achievement before and after the treatment

Table 2. Research Procedure and Treatment

\begin{tabular}{|c|c|c|}
\hline Activities & Experimental Group & Control Group \\
\hline \multicolumn{3}{|c|}{ TREATMENT 1} \\
\hline Opening & $\begin{array}{l}\text { Checking the students' attendance } \\
\text { Apperception }\end{array}$ & $\begin{array}{l}\text { Checking the students' attendance } \\
\text { Apperception }\end{array}$ \\
\hline \multirow{2}{*}{ Teaching } & $\begin{array}{l}\text { Explaining the materials about } \\
\text { narrative text to students }\end{array}$ & $\begin{array}{l}\text { Explaining the materials about } \\
\text { narrative text to students }\end{array}$ \\
\hline & $\begin{array}{l}\text { Asking the taught materials the } \\
\text { students }\end{array}$ & $\begin{array}{l}\text { Asking the taught materials to the } \\
\text { students }\end{array}$ \\
\hline & $\begin{array}{l}\text { Teaching the narrative text by using } \\
\text { an animation video }\end{array}$ & $\begin{array}{l}\text { Teaching the narrative text with } \\
\text { conventional way using whiteboard as } \\
\text { the media }\end{array}$ \\
\hline Closing & Closing the meeting & Closing the meeting \\
\hline \multicolumn{3}{|c|}{ TREATMENT 2} \\
\hline Opening & $\begin{array}{l}\text { Checking the students' attendance } \\
\text { Apperception }\end{array}$ & $\begin{array}{l}\text { Checking the students' attendance } \\
\text { Apperception }\end{array}$ \\
\hline \multirow{3}{*}{ Teaching } & $\begin{array}{l}\text { Teaching the narrative text by using } \\
\text { an animation video }\end{array}$ & Giving assingments to the students \\
\hline & $\begin{array}{l}\text { Asking the students to observe the } \\
\text { story played in the video }\end{array}$ & $\begin{array}{l}\text { Asking the students to rearrange the } \\
\text { sentences to make a story in the text } \\
\text { written in the whiteboard }\end{array}$ \\
\hline & $\begin{array}{l}\text { Asking the students to explain the } \\
\text { story played in the video }\end{array}$ & $\begin{array}{l}\text { Asking the students to tell the story } \\
\text { based on the arrangement of the text } \\
\text { written in the whiteboard }\end{array}$ \\
\hline Closing & Teacher close the meeting & Teacher close the meeting \\
\hline \multicolumn{3}{|c|}{ TREATMENT 3} \\
\hline & $\begin{array}{l}\text { Checking the students' attendance } \\
\text { Apperception }\end{array}$ & $\begin{array}{l}\text { Checking the students' attendance } \\
\text { Apperception }\end{array}$ \\
\hline \multirow{2}{*}{ Teaching } & $\begin{array}{l}\text { Asking the students to mention the } \\
\text { character, and setting of the story } \\
\text { played in video }\end{array}$ & $\begin{array}{l}\text { Asking the students to mention the } \\
\text { character, and setting of the story in } \\
\text { the text written in the whiteboard }\end{array}$ \\
\hline & $\begin{array}{l}\text { Asking the students to mention the } \\
\text { generic structure of the story played } \\
\text { in the video }\end{array}$ & $\begin{array}{l}\text { Asking the students to mention the } \\
\text { generic structure of the story written in } \\
\text { the text written in the whiteboard }\end{array}$ \\
\hline Closing & Teacher close the meeting & Teacher close the meeting \\
\hline \multicolumn{3}{|c|}{ TREATMENT 4} \\
\hline Opening & $\begin{array}{l}\text { Checking the students' attendance } \\
\text { Apperception }\end{array}$ & $\begin{array}{l}\text { Checking the students' attendance } \\
\text { Apperception }\end{array}$ \\
\hline
\end{tabular}

\section{FINDINGS AND DISCUSSION}

Results

As it seen in table 3, the result revealed that in terms of the EFL narrative writing achievement, the students under the experimental group $(x=83.22)$ outperformed those under the control group $(x=$ 76.00). 
Table 3. The Results of Descriptive Statistics

\begin{tabular}{llllll} 
& N & Minimum & Maximum & Mean & $\begin{array}{c}\text { Std. } \\
\text { Deviation }\end{array}$ \\
\hline $\begin{array}{l}\text { Post-test (Experimental } \\
\text { Group) }\end{array}$ & 32 & 68 & 96 & 83.22 & 7.979 \\
\hline Post-test (Control & 32 & 56 & 92 & 76.00 & 9.824 \\
\hline
\end{tabular}

The spreading scores found in terms of their frequencies varied. As it is showed in figure 1, in the experimental group, students who got most 80 were the most in number, i.e. 6 students; meanwhile four students got 92,88 , and 78 subsequently. In addition, only one student who obtained 90 , one obtained 91, and one obtained 96 . There were more than one, but less than four other students who got various other scores. It means that more higher scores (the scores higher than the mean score) were spreading throughout in terms of their frequencies.

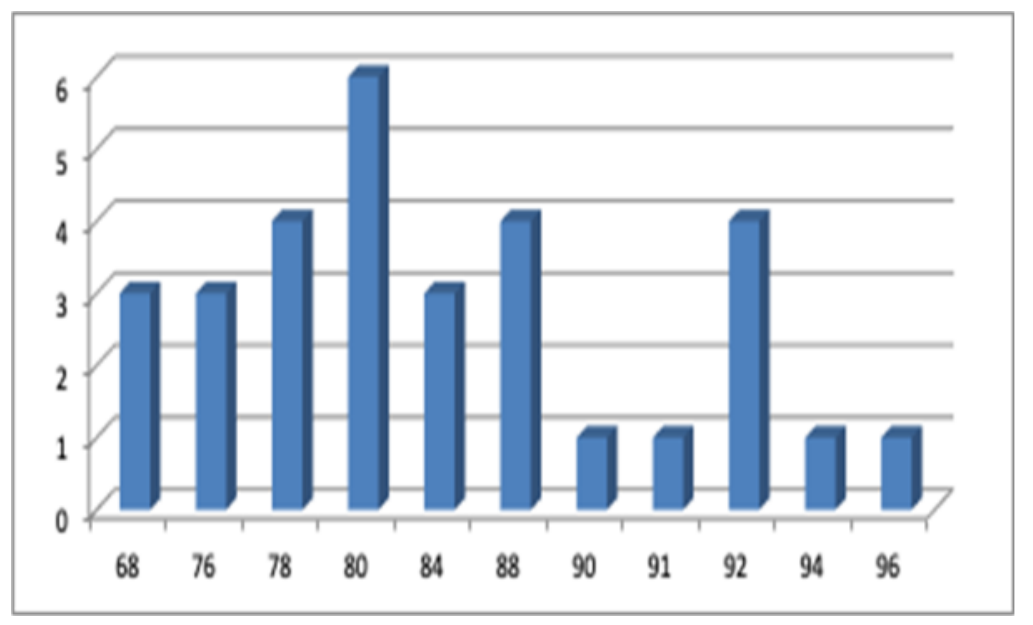

Figure 1. The results of post test scores in the experimental group

Meanwhile, in the control group different spreading scores happened. As it is seen in figure 2, there were six students who got 80; five others obtained 84 and the other five got 76 . Moreover, there were four students who got 60 and only one got 92; in the meantime, two students got 56, three students got 72 , one student got 74 , and two others got 78 . This means lower scores (the scores lower than the mean score) were spreading more active throughout the frequencies. It implies low EFL narrative writing scores happening in the control group (see figure 2).

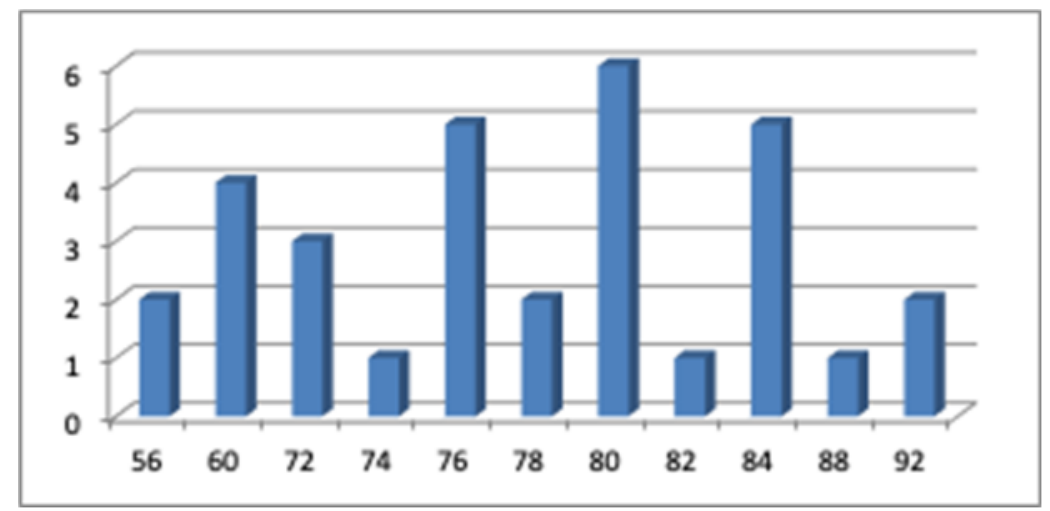

Figure 2. The results of post test scores in the control group 
To know whether or not there is significant difference between control and experimental group, the researchers used independent t-test. The steps were to checking the normality, homogeneity of variance, and checking the hypothesis. The normality test is to reveal that the samples are in normal distribution. The homogeneity test is to reveal that both samples of experiment group and control are homogeneous.

The researchers also analyzed the samples of this research. It was because the samples should be checked if the distribution of every variable in the data was normally distributed. Therefore, the normality of the data could be checked by using Kolmogorov-Smirnov. Thus, the table below showed the result of the normality of the data.

Table 4. The results of One-Sample Kolmogorov-Smirnov Test

\begin{tabular}{cccc}
\hline Group & Sig. & $\boldsymbol{\alpha}$ & $\begin{array}{c}\text { Distribution of } \\
\text { Normality }\end{array}$ \\
\hline Post-test Control Group & 0.189 & 0.050 & Normal \\
\hline $\begin{array}{c}\text { Post-Test Experimental } \\
\text { Group }\end{array}$ & 0.245 & 0.050 & Normal \\
\hline
\end{tabular}

Table 4 presented the result of Kolmogorov-Smirnov' normality data of this research. That result showed that the significance value of the two groups was higher than 0,05 (Sig. $>0,05$ ). If the result of significant is more than 0,05 (Sig. (2-tailed) $>0,05$ or $\geq 0,05$ ), then the distribution of data was normal. It means that the data of this research was normal because the significant scores is more than 0,05 (Sig. 2-tailed) $>0,05$ ).

The data also was calculated using parametric statistics which is required homogeneity of the research. Homogeneity means the samples of the research come from the same variance or have same characteristics. Meanwhile, table 5 showed the homogeneity of variances that was analyzed by using Levence statistic.

Table 5. The Result of Homogeneity of Variances

\begin{tabular}{cccc}
\hline Levene Statistics & df $\mathbf{1}$ & df $\mathbf{2}$ & Sig. \\
\hline .240 & 1 & 62 & .626
\end{tabular}

As seen in table 5 , the data showed that $F$ value of 0.240 with df1 was 1 , the $\mathrm{df} 2$ was 62 and significance was 0.626 . It means that the data was significant because $0.626>0.05$ and the data are homogeneous.

An independent t-test was conducted to know whether there is a significant difference between narrative writing achievement of the students under the experimental group and those under the control group. As shown in Table 6, results from an independent samples $t$ test indicated that students in the experimental group $(\mathrm{M}=83.22, \mathrm{SD}=7.979, \mathrm{~N}=32)$ scored higher on their narrative writing achievement than students in the control group $(\mathrm{M}=76.00, \mathrm{SD}=9.824, \mathrm{~N}=32), \mathrm{t}(32)=3.227, \mathrm{p}<$ .002 , two-tailed.

Table 6. The Result of Independent Sample t-test

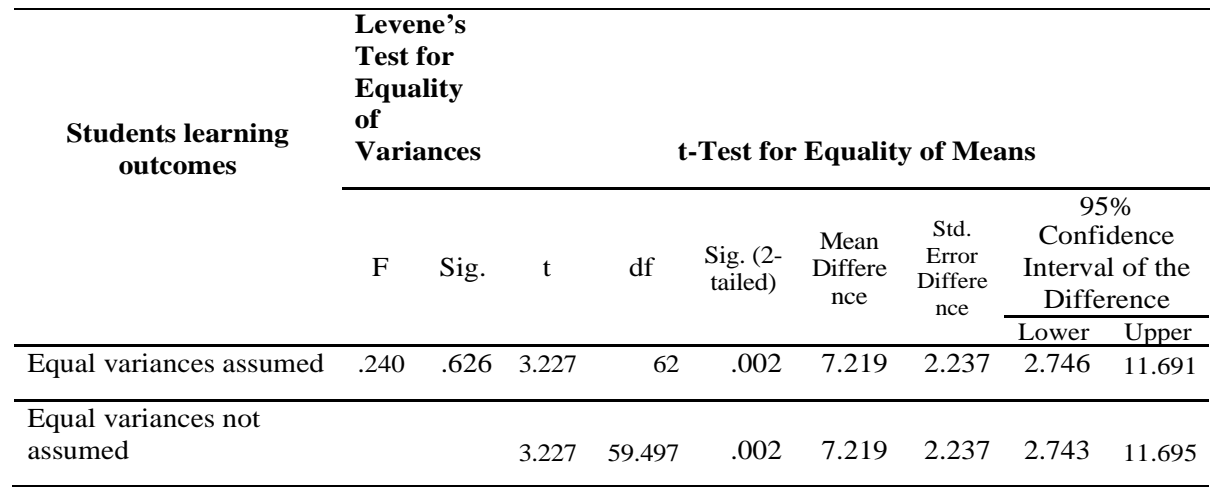


Thus, it can be concluded that the null hypothesis is rejected. This means that there is a significant effect of short animation video on the narrative EFL writing achievement of the $8^{\text {th }}$ Graders of Junior High School.

\section{Discussion}

It has been apparently proved that there is a significant effect of short animation video on the narrative EFL writing achievement of the $8^{\text {th }}$ Graders of Junior High School. This implies the importance of teaching EFL by using short animation video, as it is in line with some previous findings, for instance, explainer video was claimed both qualitatively and quantitatively can outperform the narrative writing achievement of EFL students of Muhammadiyah University (Akib \& Syatriana, 2019), short animations with dialogue was argued effective to increase EFL oral and written ability (Marashi \& Adiban, 2017), short video used in group discussion was evidently effective in teaching speaking to Indonesian EFL students (Masruddin, 2018), short English video can also improve learners' vocabulary mastery (Haslida, 2019), Plotagon can create learners' motivation to write (Guzmán Gámez \& Moreno Cuellar, 2019), tailor-made animated cartoons presumably were mentioned as a good facilitator for learners' way of writing punctuation rules in English (Bakla, 2019), for the flipped classroom, different modalities of videos was needed for English writing classes (Umutlu \& Akpinar, 2020 ), short stories through computers was implemented in language classrooms to have very positive effects on learners' language learning process (Yilmaz, 2015), WhatsApp group used as media for learning in English writing (Wahyuni \& Febianti, 2019), and silent short movie was claimed to give a significant effect on the students' achievement in EFL narrative writing (Kartika et al., 2017). Having similar conclusions with some other previous findings, indeed, this current study appeared to strengthen the wide prism of technology praxis in EFL teaching, especially in EFL narrative writing. As one of the most effective media used in the teaching during the pandemic circumstances, animation video functioned to be a means for transferring messages in the process of teaching.

It is true then that technology and its function are really necessary media in the process of teaching and learning, especially video. Video used as media in learning can function as helping students organize events in their mind when they are learning, for instance it might catch events happening too fast since in video everything can be recorded dan replayed. In addition, video provides visual elements which is helpful for the learners and learners also experience audio element (Newby, 2002); Richards \& Renandya 2002). Accordingly, the students are able to happily manage the circumstance when learning, hence they can easily create the idea by using media in learning. In brief, using video makes the students easier in learning EFL as it is implied in the findings revealed in the current study.

Moreover, this current study provides pedagogical implication that short animation video was used a media in a learning circumstance which is in regard with the process of EFL writing in secondary schools. This pedagogical conclusion has a similar notion in terms of using short animation video in EFL writing, however, what is relatively new is that this happens in Indonesian secondary schools in which large classes are very common. Large number-students managed in every classroom of the secondary schools should be taught using appropriate media in order that fun and optimal class circumstances can be obtained by the teachers.

\section{CONCLUSION}

The current study draws a conclusion that the students under the experimental group ( $M=83.22$, SD $=7.979, \mathrm{~N}=32$ ) performed higher in scores on their narrative writing achievement than the students under the control group $(\mathrm{M}=76.00, \mathrm{SD}=9.824, \mathrm{~N}=32), \mathrm{t}(32)=3.227, \mathrm{p}<.002$, two-tailed. It means there is a significant difference between narrative writing achievement of the students under the experimental group and those under the control group. This means that there is a significant effect of short animation video on the narrative EFL writing achievement of the $8^{\text {th }}$ Graders of Junior High School. Having such a conclusion, the study gives a pedagogical implication that short animation video might be presumably important as media of technology in increasing the effective process learning narrative writing for EFL students in the secondary schools. In an education science, especially instructional science, the effective learning process helps both teachers and students accomplish their goals of learning, i.e improving the quality of learners' life in the future. Spesifically, in terms of EFL learning, such life quality improvement might be related to good communication skills with people from different countries and cultures. As a result, this brings an ease of culturalization process in the international global village. 


\section{REFERENCES}

Akib, E., \& Syatriana, E. (2019). Engaging EFL Learner in Explainer Video for Creative Writing. 4th Progressive and Fun Education International Conference (PFEIC 2019), 119-123. https://www.atlantis-press.com/proceedings/pfeic-19/125920174

Amin, J. N. (2016). Redefining the role of teachers in the digital era. The International Journal of Indian Psychology, 3(3), 40-45. https://doi.org/18.01.101/20160303

Bakla, A. (2019). A mixed-methods study of tailor-made animated cartoons in teaching punctuation in EFL writing. ReCALL, https://doi.org/https://doi.org/10.1017/S0958344018000046

Brewster, J., Ellis, G., \& Girard, D. (2002). The Primary English Teacher's Guide. (Second Edition). Harlow Essex, England: Pearson Education Limited.

Cakir, I. (2006). The use of video as an audio-visual material in foreign language teaching classroom. Turkish Online Journal of Educational Technology-TOJET, 5(4), 67-72.

Celce-Murcia, M., \& Olshtain, E. (2000). Discourse and Context in Language Teaching. A guide for language teachers. Cambridge: Cambridge University Press.

Flores, M. A. (2020). Preparing teachers to teach in complex settings: opportunities for professional learning and development. European Journal of Teacher Education, 43(3), 297-300. https://doi.org/10.1080/02619768.2020.1771895

Grenville, K. (2001). Writing from Start to Finish: A Six-Step Guide. Crows Nest NSW, Australia: Allen \& Unwin.

Guzmán Gámez, D. Y., \& Moreno Cuellar, J. A. (2019). The use of plotagon to enhance the english writing skill in secondary school students. Profile Issues in TeachersProfessional Development, 21(1), $139-153$.

Harmer, J. (2007). How to teach English. Harlow Essex, England: Pearson Education Limited.

Haslida, S. N. (2019). The Use of Short English Video to Improve Students' Vocabulary. Banda Aceh:Unpublished Doctoral Dissertation, UIN Ar-Raniry Banda Aceh.

Irawati, D. (2016). Supporting student's English speaking achievement using Video. IJEFL, 1(1), 4560.

Kartika, R. A. R., Susilo, S., \& Natsir, M. (2017). The effect of silent short movie on EFL writing achievement of Vocational High School students. Jurnal Pendidikan Vokasi, 7(2), 168-179. https://doi.org/10.21831/jpv.v7i2.14191

Knapp, P., \& Watkins, M. (2005). Genre, text, grammar: Technologies for teaching and assessing writing. Australia: UNSW Press.

Langan, John. (2008). English Skills with Readings. $7^{\text {th }}$ Edition. Starlette Vaughn, Sacramento City College: McGraw-Hill

Machili, I., Papadopoulou, I., \& Kantaridou, Z. (2020). Effect of strategy instruction on EFL students' video-mediated integrated writing performance. Journal of Second Language Writing, 48(June), $100-708$.

Mahajan, G. (2012). Multimedia in teacher education: Perceptions \& uses. Journal of Education and Practice, 3(1), 5-13.

Marashi, H., \& Adiban, H. (2017). The effect of using short silent animations on EFL learners'writing. English Review: Journal of English Education, 5(2), 207-216.

Masruddin, M. (2018). The efficacy of using short video through group work in teaching speaking to Indonesian English as Foreign Language (EFL) students. Arab World English Journal (AWEJ) Volume, 9, 282 - 293.

Napal, M., Mendióroz-Lacambra, A. M., \& Peñalva, A. (2020). Sustainability teaching tools in the digital age. Sustainability (Switzerland), 12(8), 1-14. https://doi.org/10.3390/SU12083366

Newby, D. (2002). Safety in Psychiatry: the Mind's Eye By The Royal College of Psychiatrists. Psychiatric Bulletin, 26(11), 439-440.

O'Dowd, R., Sauro, S., \& Spector-Cohen, E. (2019). The Role of Pedagogical Mentoring in Virtual Exchange. TESOL Quarterly, 54(1), 146 - 172. https://doi.org/10.1002/tesq.543

Richards, J. C., \& Renandya, W. A. (2002). Methodology in language teaching: An anthology of current practice. Cambridge: Cambridge University Press.

Riddel, D. (2003). Teaching English as a Second or Foreign Language. London: Hodder Headline, Ltd.

Rosa, S. S., Coutinho, C. P., \& Flores, M. A. (2016). Online Peer Assessment: Method and Digital Technologies. Procedia - Social and Behavioral Sciences, 228(June), 418-423. 
https://doi.org/10.1016/j.sbspro.2016.07.064

Smaldino, S. E., Lowther, D. L., \& Russell, J. D. (2011). Teknologi Pembelajaran dan media untuk belajar. Jakarta: Kencana Prenada Media Group.

Smalley, R. L., Ruetten, M. K., \& Kozyrev, J. R. (2001). Refining composition. Boston, M.A: Heinle \& Heinle Publishers.

Umutlu, D., \& Akpinar, Y. (2020). Effects of Different Video Modalities on Writing Achievement in Flipped English Classes. Contemporary Educational Technology, 12(2), 1 - 16.

Wahyuni, S., \& Febianti, K. (2019). The use of WhatsApp group discussion to improve students' writing achievement. Indonesian Educational Administration and Leadership Journal, 1(1), 45-51.

Yilmaz, A. (2015). Short stories via computers in EFL classrooms: An empirical study for reading and writing skills. The Reading Matrix, 15(1), 41-53. 